\title{
Oil Price Shocks, Fuel Subsidies and Macroeconomic (In)stability in Nigeria
}

\begin{abstract}
Babatunde S. Omotosho ${ }^{1,2}$
This paper studies the macroeconomic implications of oil price shocks and the extant fuel subsidy regime for Nigeria. To do this, we develop and estimate a New-Keynesian DSGE model that accounts for pass-through effect of international oil price into the retail price of fuel. Our results show that oil price shocks generate significant and persistent impacts on output, accounting for about 22 percent of its variations up to the fourth year. Under our benchmark model (i.e. with fuel subsidies), we show that a negative oil price shock contracts aggregate GDP, boosts non-oil GDP, increases headline inflation, and depreciates the exchange rate. However, results generated under the model without fuel subsidies indicate that the contractionary effect of a negative oil price shock on aggregate GDP is moderated, headline inflation decreases, while the exchange rate depreciates more in the short-run. Counterfactual simulations also reveal that fuel subsidy removal leads to higher macroeconomic instabilities and generates non-trivial implications for the response of monetary policy to an oil price shock. Thus, this study cautions that a successful fuel subsidy reform must necessarily encompass the deployment of well-targeted safety nets as well as the evolution of sustainable adjustment mechanisms.
\end{abstract}

Keywords: Fuel subsidies, Oil price shocks, Oil price pass-through

JEL classification: E31, E32, E52, E62

DOI: $10.33429 /$ Cjas.10219.1/6

\subsection{Introduction}

There is a large body of research investigating the macroeconomic implications of oil price shocks as well as the role of fuel subsidies, especially in resource-rich emerging economies (Adenikinju, 2009;

\footnotetext{
${ }^{1}$ The author is a staff of Statistics Department, Central Bank of Nigeria, Abuja and currently a Doctoral student at the Adam Smith Business School, University of Glasgow, United Kingdom. This paper is an extract from the author's Ph.D dissertation. bsomotosho@gmail.com.

${ }^{2}$ The views expressed in this paper are purely those of the author, and do not represent the views of the Central Bank of Nigeria or Adam Smith Business School.
} 
Adeniyi et al., 2011; Bazilian and Onyeji, 2012; Berument et al., 2010; Coady et al., 2017; Krane and Monaldi, 2017). The interest in this area of research grew following the work of Hamilton (1983), which showed that seven out of the eight post-World War II recessions were preceded by significant oil price increases. Almost four decades after Hamilton (1983), empirical evidence still abounds regarding the non-trivial influence of oil price shocks on both domestic economies and the global economy at large (Fueki et al., 2018). In order to ameliorate the welfare and macroeconomic impacts of oil price shocks, fuel subsidy programmes have been implemented in several countries, especially the oil-producing ones (Di Bella et al., 2015; Estache and Leipziger, 2009).

In recent times, however, there has been an increasing call for fuel subsidy reforms globally as policy-makers have expressed concerns regarding the efficacy of such programmes as well as its implications for fiscal sustainability $^{3}$ (see, for example, Sdralevichet et al, 2014; Coady et al., 2015; Ebeke and Ngouana, 2015; Jakob et al., 2015; Salehi-Isfahani et al., 2015). It has also been argued that, contrary to its intention, badly-targeted subsidy programmes have worsened the problem of inequality. Consequently, a subset of the literature on oil-macroeconomy relationship has focused on the potential impacts of fuel subsidy reforms on domestic economies of oil-producing countries (Alleyne and Hussain, 2013; Anand et al., 2013; Clements et al., 2013; Calvo-Gonzalez et al., 2015; Breton and Mirzapour, 2016; Dennis, 2016). Our research falls within this strand of the literature, taking the case of Nigeria.

Oil plays important roles in the Nigerian economy, contributing about a third of the country's gross domestic product (GDP) in the 1980s and 1990s. Although its share of the economy has waned in the subsequent decades due to declining oil prices and the changing structure of the economy, the oil and gas sector still accounts for about 11.2 per cent of the GDP in the current decade (Table 1). Also, the contribution of oil to government revenue has remained quite high, increasing from 70.2 per cent during the 1980s to about 80.0 per cent in the last decade. In terms of trade, oil accounts for about 93.1 per cent of exports and 24.4 per cent of

\footnotetext{
${ }^{3}$ Clements et al., (2013) lists the consequences of fuel subsidies to include: aggravating fiscal imbalances, crowding-out priority public spending, and depressing private investment, distorting resource allocation by encouraging excessive energy consumption, and accelerating the depletion of natural resources, amongst others.
} 
imports during the period 2010-2018 ${ }^{4}$. Against this backdrop, several studies have investigated the macroeconomic impacts of oil price shocks on the Nigerian economy. Amongst other effects, it has been shown that oil price shocks generate significant implications for output, prices, exchange rate, government revenues, interest rates and external reserves (Adeniyi et al., 2011; Akinlo, 2012; Akinleye and Ekpo, 2013; Abayomi et al., 2015; Abdulkareem and Abdulhakeem, 2016; Aigheyisi, 2018; ). However, only a few attempts have been made at studying the role of fuel subsides and the macroeconomic implications of its removal (Adenikinju, 2009).

Table 1: Oil and the Nigerian economy, $1980-2018$

\begin{tabular}{ccccc}
\hline & $1980-1989$ & $1990-1999$ & $2000-2009$ & $2010-2018$ \\
\hline $\begin{array}{c}\text { Share of oil } \\
\text { in GDP (\%) }\end{array}$ & 31.23 & 31.99 & 24.07 & 11.21 \\
$\begin{array}{c}\text { Share of oil } \\
\text { in govt. } \\
\text { revenue (\%) }\end{array}$ & 70.19 & 77.11 & 79.85 & 64.77 \\
$\begin{array}{c}\text { Share of oil } \\
\text { in total } \\
\text { exports (\%) }\end{array}$ & 95.14 & 97.35 & 96.97 & 93.05 \\
$\begin{array}{c}\text { Share of fuel } \\
\text { in total } \\
\text { imports (\%) }\end{array}$ & 8.39 & 20.12 & 21.30 & 24.41 \\
\hline
\end{tabular}

Source: CBN Statistical Bulletin

As in many other resource-rich countries, the Nigeria government introduced a fuel subsidy regime as part of strategies for cushioning the macroeconomic impacts of oil price shocks on the economy. Under this arrangement, the government regulates the domestic price of fuel and pays domestic marketers the difference between the regulated domestic price and the Expected Open Market Price (EOMP), which is determined by the

\footnotetext{
${ }^{4}$ About 91 per cent of Nigeria's fuel requirement is imported from the rest of the world due to poor domestic refining capacity.
} 
Petroleum Products Pricing and Regulatory Agency (PPPRA) $)^{5}$. It is estimated that about $\$ 10$ trillion was spent in fuel subsidy payments during the period 2006-2018 (Budgit, 2019).

Many studies have focused on examining the implications of fuel subsidy for the Nigerian economy. For instance, Umar and Umar (2013) and Siddig et al. (2014) noted that Nigeria's subsidy regime distorts fiscal planning, encourages inefficient consumption, and increases inequality as richer households benefit more. Siddig et al. (2014) further showed that subsidy reduction increases the GDP and reduces household income. It has also been shown that fuel subsidy removal in Nigeria could cause inflation and reduce economic welfare (Adenikinju, 2009); hurt economic growth and reduce household income (Ocheni, 2015); and make firms less competitive (Bazilian and Onyeji, 2012). These studies applied either the computable general equilibrium model (Siddig et al., 2014; Adenikinju, 2009), analysis of survey data (Ocheni, 2015), or the narrative approach (Bazilian and Onyeji, 2012).

In this paper, we argue that assessing the macroeconomic implications of oil price shocks and subsidy reforms requires a good understanding of the pass-through effects of oil price shocks to domestic fuel price ${ }^{6}$. Thus, we depart from previous studies by estimating the pass-through effect of oil prices into domestic fuel price within a general equilibrium framework prior to investigating the impacts of oil price shocks. To our knowledge, this paper represents the first attempt at incorporating fuel subsidy into a Dynamic Stochastic General Equilibrium (DSGE) model for Nigeria and estimating the pass-through effect of oil prices into domestic fuel price. Thus, we make empirical contributions to the existing literature. Next, we investigate the potential implications of fuel subsidy removal on the Nigerian economy by simulating our estimated model under alternative assumptions regarding the size of the pass-through effect. In other words, we simulate two economies: one with fuel subsidies (i.e. incomplete pass-

\footnotetext{
${ }^{5}$ This agency was established in 2003 to amongst others design the pricing policy of petroleum products in Nigeria

${ }^{6}$ While the domestic retail fuel price is administered by the federal government, the effective price paid by economic agents often differs from one part of the country to another. Such differences are usually amplified during periods of product scarcity as there is lack of institutional capacity to enforce country-wide compliance by fuel retailers. To capture this reality, we assume that part of the changes to international price of fuel is unofficially passed to domestic consumers of fuel.
} 
through) and the other without fuel subsidies (i.e. complete pass-through). Thus, the objective of this paper is to examine the impacts of oil price shocks on Nigeria's macroeconomy and investigate the effects of fuel subsidy removal on key macroeconomic variables such as output, consumption, inflation and the real effective exchange rate.

The paper is organized into five sections. In the next section, we present a DSGE model for a resource-rich, resource-dependent emerging economy in the fashion of Gali and Monacelli (2005) and Medina and Soto (2007) ${ }^{7}$. Thus, the economic environments within which the model agents operate as well as the optimality conditions guiding their decisions are described in the section. In the third section, the estimation procedure as well the data used for the empirical investigation are discussed. The estimation results, including the impulse responses and variance decompositions are presented in section four while section five concludes the paper with policy implications.

\subsection{The Model}

The model we develop in this paper is an extension of Gali and Monacelli (2005) and it incorporates: (i) an oil sector that is owned by government and foreign investors as in Algozhina (2015); (ii) oil in household consumption basket and firms' production technology as in Medina and Soto (2005) and Allegret and Benkhodja (2015); (iii) an inefficient financial sector as in Smets and Wouters (2007); (iv) fiscal policy rule as in Algozhina (2015); (v) a fuel pricing rule that connotes an implicit subsidy regime as in Allegret and Benkhodja, (2015); and (vi) nonRicardian consumers to capture credit constraints ${ }^{8}$. Furthermore, we allow for the law of one price gap in imports and by implication assume incomplete exchange rate pass-through into import prices (Monacelli, 2005; Senbeta, 2011). Finally, we allow for nominal and real rigidities including wage and price stickiness; consumption habits; and investment adjustment costs. There are seven agents operating in the economy: households, non-oil intermediate goods producers, final goods producers, oil firm, importing firms, government, and the central bank. In what

\footnotetext{
${ }^{7}$ Some previous applications of DSGE models to Nigerian data include Alege (2012); Olayeni and Olabode (2013); Adebiyi and Mordi (2016); and Iklaga (2017).

${ }^{8}$ A survey conducted in 2018 showed that about 36.8 per cent of adults in Nigeria are financially excluded that year (EFInA, 2018).
} 
follows, we discuss the economic environments within which each of the agents operates as well as the rules guiding their decisions.

\subsection{Households}

The economy is populated by Ricardian $(R)$ and non-Ricardian $(N R)$ households. The former represents a fraction $\left(\gamma_{R}\right)$ of households who have access to the financial markets and are capable of inter-temporal optimisation. On the other hand, the latter category, $N R$, are financiallyconstrained and completely consume their labour income within the period (Gabriel et al., 2010). However, both categories share identical preferences as the representative household $j$ derives utility from private consumption, $C_{t}$, as well as government consumption, $G_{c, t}$ and dis-utility from labour, $N_{t}$. Thus, they seek to maximise the expected discounted utility function

$$
\begin{aligned}
U_{0}=E_{0} \sum_{s=0}^{\infty} \beta^{s} & {\left[\frac{\left(C_{t+s}(j)-\emptyset_{c} C_{t+s-1}\right)^{1-\sigma}}{1-\sigma}-\frac{N_{t+s}(j)^{1+\varphi}}{1+\varphi}\right.} \\
\left.+h\left(G_{c, t+s}\right)\right] &
\end{aligned}
$$

where $\beta \in(0,1)$ is a discount factor, $\sigma$ is relative risk aversion coefficient, and $\varphi>0$ is the inverse of the Frisch elasticity of labour supply. $E_{0}$ denotes the mathematical expectation operator. The utility derived by household from government spending, $h\left(G_{c, t}\right)$, is taken as given. Household consumption is subject to external habit formation, where the parameter $\emptyset_{c} \in(0,1)$ measures the degree of consumption habit.

Household consumption is a composite index comprising core (non-oil) consumption bundle, $C_{n, o, t}(j)$, and fuel (oil) consumption, $C_{O, t}(j)$. Expenditure minimization by each household yields the optimal demand for core and fuel consumption bundles as follows:

$$
\begin{aligned}
C_{n o, t}(j) & =\left(1-\gamma_{o}\right)\left[\frac{P_{n o, t}}{P_{t}}\right]^{-\eta_{o}} C_{t}(j), \quad C_{o, t}(j) \\
= & \gamma_{o}\left[\frac{P_{r o, t}}{P_{t}}\right]^{-\eta_{o}} C_{t}(j),
\end{aligned}
$$

where parameter $\eta_{O}>0$ measures the degree of substitution between core and fuel consumption and $\gamma_{O}$ represents the share of fuel consumption, $C_{O, t}(j)$ in domestic consumption. The price of fuel and core goods are denoted as $P_{r o, t}$ and $P_{n o, t}$, respectively, and $P_{t}$ is the aggregate consumer 
price index. The domestic price of fuel, $P_{r o, t}$ is regulated based on a fuel pricing rule that is discussed in section 2.6.

Similarly, the core consumption bundle, $C_{n o, t}(j)$ combines imported bundle, $C_{f, t}(j)$ and domestically produced goods, $C_{h, t}(j)$. Households' expenditure minimisation subject to the composite index for the goods yields the optimal demands for $C_{f, t}(j)$ and $C_{h, t}(j)$ as follows:

$C_{h, t}(j)=\left(1-\gamma_{C}\right)\left[\frac{P_{h, t}}{P_{n o, t}}\right]^{-\eta_{C}} C_{n o, t}(j), \quad C_{f, t}(j)=\gamma_{C}\left[\frac{P_{f, t}}{P_{n o, t}}\right]^{-\eta_{C}} C_{n o, t}(j)$, where $P_{h, t}$ represents the price of domestically produced goods and $P_{f, t}$ is the domestic price of imported goods. The parameter $\eta_{C}>0$ represents the elasticity of substitution between home and foreign goods in the core consumption basket while $\gamma_{C}$ indicates the degree of openness of the domestic economy. The headline consumer price index (CPI), $P_{t}$, and its core counterpart, $P_{n o, t}$, are standard:

$$
\begin{aligned}
P_{t}=\left[\left(1-\gamma_{O}\right) P_{n o, t}^{1-\eta_{O}}+\gamma_{O} P_{r o, t}^{1-\eta_{O}}\right]^{\frac{1}{1-\eta_{O}}}, \quad P_{n o, t} \\
=\left[\left(1-\gamma_{C}\right) P_{h, t}^{1-\eta_{C}}+\gamma_{C} P_{f, t}^{1-\eta_{C}}\right]^{\frac{1}{1-\eta_{C}}} .
\end{aligned}
$$

\subsubsection{Ricardian households}

Each household $j$ in this category can buy and sell financial assets without any form of constraints. Thus, the representative household makes intertemporal decisions by maximising equation (1) subject to the following per period budget constraint

$$
\begin{aligned}
P_{t} C_{t}^{R}(j)+P_{i, t} & I_{n o, t}(j)+\frac{B_{t+1}(j)}{R_{t} \mu_{t}}+\frac{\epsilon_{t} B_{t+1}^{*}(j)}{R_{t}^{*} \mu_{t}^{*}} \\
& =W_{t} N_{t}^{R}(j)+R_{h, t} K_{h, t}(j)+B_{t}(j)+\epsilon_{t} B_{t}^{*}(j)+D_{t} \\
& -T X_{t} .
\end{aligned}
$$

where the superscript $R$ indicates that the household is Ricardian. On the income side of equation (2), the representative Ricardian consumer supplies $N_{t}^{R}(j)$ hours of work at a nominal wage rate, $W_{t}$, and earns a labour income, $W_{t} N_{t}^{R}(j)$. It also earns capital income, $R_{h, t} K_{h, t}(j)$ by leasing an amount of non-oil capital, $K_{h, t}(j)$, to the domestic non-oil firms at a rental rate, $R_{h, t}$. Each household enters the period with a stock of nominal domestic bonds, $B_{t}(j)$, and foreign bonds, $B_{t}^{*}(j)$ maturing in period $t+1$. The domestic bond pays a gross nominal rate of return, $R_{t}$ in domestic currency while its foreign counterpart pays an exchange rate 
$\left(\epsilon_{t}\right)$ adjusted nominal rate of return, $R_{t}^{*}$. Following Gupta et al., (2016) and Smets and Wouters (2007), we allow for domestic risk premium, $\mu_{t}$ over the monetary policy rate when households hold domestic assets as well as a stochastic disturbance term that represents the risk premium faced by households when borrowing abroad, $\mu_{t}^{*}$. The foreign and domestic risk premia are driven by $A R(1)$ processes with independent and identically distributed (i.i.d) innovations. The household receives an aliquot share, $D_{t}$ from the profits of the firms. The income received is used to finance the purchase of consumption goods, $C_{t}^{R}(j)$, and non-oil investment goods, $I_{n o, t}(j)$ at their respective prices, $P_{t}$ and $P_{i, t}$. Finally, $T X_{t}$ represents per-capita lump-sum net taxes.

As with consumption, non-oil investment goods, $I_{n o, t}$, in equation (2) comprise home-produced, $I_{h, t}$, and foreign-produced, $I_{f, t}$ with their respective optimal demands and price indices. The capital accumulation process is given by

$$
\begin{aligned}
K_{h, t+1}(j)=(1 & \left.-\delta^{h}\right) K_{h, t}(j) \\
& +I_{n o, t}(j)\left[1-S\left(\frac{I_{n o, t}(j)}{I_{n o, t-1}(j)}\right)\right],
\end{aligned}
$$

where the parameter $0<\delta^{h}<1$ represents the capital depreciation rate. The investment adjustment cost function is defined as:

$$
\mathrm{S}\left(\frac{I_{n o, t}(j)}{I_{n o, t-1}(j)}\right)=\frac{\chi}{2}\left(\frac{I_{n o, t}(j)}{I_{n o, t-1}(j)}-1\right)^{2},
$$

where the parameter $\chi \geq 0$ governs the size of the adjustment cost. The representative Ricardian household maximises equation (1) subject to a per period nominal budget constraint (equation 2) and a capital accumulation process (equation 3). The relevant first order conditions yield the equations for consumption Euler, demand for foreign bonds, supply of capital, and demand for investment goods.

\subsubsection{Non-Ricardian households}

The second category of households are non-Ricardian - i.e. creditconstrained. They are therefore incapable of inter-temporal optimisation. Thus, the representative non-Ricardian consumer $j$ chooses its consumption, $C_{t}^{N R}(j)$ by maximising a utility function that is similar to equation (1) subject to the following budget constraint: 


$$
P_{t} C_{t}^{N R}(j)=W_{t} N_{t}^{N R}(j)-T X_{t}
$$

\subsubsection{Labour supply and wage setting}

We allow both the Ricardian and non-Ricardian households to determine their wages à la Calvo (1983). Thus, we assume that a fraction, $1-\theta_{w}$, of households is chosen at random to optimally reset their wages each period while the remaining fraction, $\theta_{w}$, stick to the wages determined previously. The optimal wage setting problem involves maximising equation (1) subject to the household budget constraints as well as the demand for the differentiated labour. The aggregate nominal wage rule is standard:

$$
W_{t}=\left[\theta_{w} W_{t-1}^{1-\eta_{w}}+\left(1-\theta_{w}\right) W_{t}^{\mathbf{m}}(j)^{1-\eta_{w}}\right]^{\frac{1}{1-\eta_{w}}}
$$

where $W_{t}(j)$ is the optimal reset wage, $\theta_{w}$ measures the degree of nominal wage rigidity, and $\eta_{w}$ is the elasticity of substitution between differentiated jobs. The economy-wide consumption, $C_{t}$, and labour, $N_{t}$, for the Ricardian and non-Ricardian households are aggregated as follows:

$$
C_{t}=\gamma_{R} C_{t}^{R}+\left(1-\gamma_{R}\right) C_{t}^{N R}, \quad N_{t}=\gamma_{R} N_{t}^{R}+\left(1-\gamma_{R}\right) N_{t}^{N R} .
$$

\subsection{Open economy features}

The interactions between the small open economy and the foreign economy is discussed next. Our exposition here follows Monacelli (2005) and Gali and Monacelli (2005). In terms of notation, we denote variables in real terms by small letters.

Real exchange rate, terms of trade and incomplete pass-through: We define the law of one price gap, $\Psi_{t}$, as the ratio of foreign price index (expressed in domestic currency) to the domestic currency price of imports:

$$
\Psi_{t}=\frac{\epsilon_{t} P_{t}^{*}}{P_{f, t}}
$$

where $P_{t}^{*}$ is aggregate consumer price index of the foreign economy and $P_{f, t}$ is the average domestic price of imported goods. It is obvious that equation (7) takes the value of unity if the law of one price (LOP) holds. The real exchange rate, $s_{t}$, is defined as

$$
s_{t}=\frac{\epsilon_{t} P_{t}^{*}}{P_{t}} \text {. }
$$


The law of one price gap can be re-written by making use of equation (8) in (7) as follows:

$$
\Psi_{t}=\frac{s_{t}}{p_{f, t}},
$$

where $p_{f, t}=P_{f, t} / P_{t}$ denotes the domestic price of imported goods in real terms. The terms of trade, $\tau_{t}$, is defined as the domestic currency price of imports relative to the export price (i.e. price of domestically produced tradable goods): $\tau_{t}=P_{f, t} / P_{h, t}$.

International risk sharing: We link domestic consumption with foreign consumption by assuming that agents in the rest of the world have access to the same set of bonds and share the same preferences with their domestic counterparts. This assumption allows us to derive the international risk sharing equation by combining the Euler equations for both the domestic and foreign economies to yield

$$
C_{t}^{R}(j)-\phi_{c} C_{t-1}=\varrho s_{t}^{\frac{1}{\sigma}}\left(C_{t}^{*}(j)-\phi_{c} C_{t-1}^{*}\right),
$$

where the definition of the real exchange rate in equation (8) has been invoked and $\varrho$ represents a constant that depends on the relative initial conditions in asset holdings.

\subsection{Non-oil goods producing firms}

Final-good firms: These perfectly competitive firms produce final goods meant for the domestic market, $Y_{h, t}$, and the export market, $Y_{h, t}^{*}$, by bundling their respective differentiated intermediate goods, $Y_{h, t}\left(z_{h}\right)$ and $Y_{h, t}^{*}\left(z_{h}\right)$. Profit maximisation subject to the firms' bundling technology yields a standard downward sloping demand function for intermediate inputs meant for domestic market $\left(Y_{h, t}\left(z_{h}\right)\right)$ and an analogous variant for goods meant for the export market $\left(Y_{h, t}^{*}\left(z_{h}\right)\right)$ as follows

$Y_{h, t}\left(z_{h}\right)=\left[\frac{P_{h, t}\left(z_{h}\right)}{P_{h, t}}\right]^{-\epsilon_{h}} Y_{h, t}, \quad Y_{h, t}^{*}\left(z_{h}\right)=\left[\frac{P_{h, t}^{*}\left(z_{H}\right)}{P_{h, t}^{*}}\right]^{-\epsilon_{h}} Y_{h, t}^{*}$

where $P_{h, t}\left(z_{h}\right)$ is the price charged on intermediate goods, $Y_{h, t}\left(z_{h}\right)$, produced by an intermediate goods-producing firm, $z_{h} . P_{h, t}$ is the domestic price index and the parameter $\epsilon_{h}>1$ represents the elasticity of substitution among different intermediate goods. Also, the corresponding price aggregators for home goods meant for the domestic market $\left(P_{h, t}\right)$ and the export market $\left(P_{h, t}^{*}\right)$ are given by: 


$$
P_{h, t}=\left[\int_{0}^{1} P_{h, t}\left(z_{h}\right)^{1-\epsilon_{h}} d z_{h}\right]^{\frac{1}{1-\epsilon_{h}}}, \quad P_{h, t}^{*}=\left[\int_{0}^{1} P_{h, t}^{*}\left(z_{h}\right)^{1-\epsilon_{h}} d z_{h}\right]^{\frac{1}{1-\epsilon_{h}}}
$$

where $P_{h, t}^{*}\left(z_{h}\right)$ is the price charged on export-bound intermediate goods $Y_{h, t}^{*}\left(z_{h}\right)$ produced by an intermediate goods-producing firm, $z_{h}$.

Intermediate goods-producing firms: A continuum of intermediate goods firms indexed by $z_{h} \in(0,1)$, producing differentiated goods in a monopolistically competitive environment combine three inputs: capital $K_{h, t}\left(z_{h}\right)$, refined oil - $O_{h, t}\left(z_{h}\right)$, and labour- $N_{t}\left(z_{h}\right)$ using a production technology:

$Y_{h, t}\left(z_{h}\right)=A_{h, t} K_{h, t}\left(z_{h}\right)^{\alpha_{h}^{k}} O_{h, t}\left(z_{h}\right)^{\alpha_{h}^{o}} N_{t}\left(z_{h}\right)^{\alpha_{h}^{n}}$,

where $Y_{h, t}\left(z_{h}\right)$ is the output of the intermediate firm $z_{h}$, and the parameters $1>\alpha_{h}^{k}>0,1>\alpha_{h}^{o}>0$ and $1>\alpha_{h}^{n}>0$ are elasticities of output with respect to capital, refined oil and labour inputs, respectively. Total factor productivity, $A_{h, t}$, follows a first order autoregressive process with i.i.d innovations. Cost minimisation subject to equation (12) yields the firms' optimal input combinations, while the corresponding real marginal cost is

$$
m c_{t}=\frac{1}{A_{h, t} p_{h, t}}\left(\frac{r_{h, t}}{\alpha_{h}^{k}}\right)^{\alpha_{h}^{k}}\left(\frac{p_{r o, t}}{\alpha_{h}^{o}}\right)^{\alpha_{h}^{o}}\left(\frac{w_{t}}{\alpha_{h}^{n}}\right)^{\alpha_{h}^{n}},
$$

where $m c_{t}=M C_{t} / P_{t}$ is the real marginal cost, $r_{h, t}=R_{H, t} / P_{t}$ is the real rental rate on capital, $p_{r o, t}=P_{r o, t} / P_{t}$ is the subsidised real domestic price of fuel, $w_{t}=W_{t} / P_{t}$ is the real wage, and $p_{h, t}=P_{h, t} / P_{t}$ is the real price of domestically produced goods. Of note is the fact that the domestic price of fuel, $p_{r o, t}$, features in the real marginal cost of the firms. Thus, administrative adjustments to $p_{r o, t}$ have consequential effects on firms' marginal cost as well as their price-setting behaviour. As shown in subsection 2.6, the evolution of $p_{r o, t}$ is driven by a pass-through parameter $(v)$ that defines the extent to which changes in the international price of oil is translated to the retail price of fuel.

Following Calvo's (1983) staggered pricing model, each firm faces a probability $\left(1-\theta_{h}\right)$ of optimally resetting its price every period while the remaining $\theta_{h}$ maintain the price as at last fixing. Profit maximisation subject to the demands for intermediate goods (equation 11) yields the optimal reset price for intermediate goods meant for the domestic market as 
$P_{h, t}^{\mathbf{M}}=\frac{\epsilon_{h}}{\epsilon_{h}-1} \frac{E_{t} \sum_{s=0}^{\infty}\left(\beta \theta_{h}\right)^{s} P_{h, t+s} Y_{h, t+s} m c_{t+s}}{E_{t} \sum_{s=0}^{\infty}\left(\beta \theta_{h}\right)^{s} Y_{h, t+s}}$

where $\theta_{h} \in[0,1]$ is an index of price stickiness and $P_{h, t}^{\bullet}$ represents the optimal reset price. Analogously, the optimal price for intermediate goods that are meant for the export market $\left(P_{h, t}^{*-\mathbf{W}}\right)$ exists with its associated Calvo parameter denoted by $\theta_{h, f}$. The law of motion for domestic price level is:

$$
P_{h, t}=\left[\theta_{h} P_{h, t-1}^{1-\epsilon_{h}}+\left(1-\theta_{h}\right)\left(P_{h, t}^{\mathbf{\bullet}}\right)^{1-\epsilon_{h}}\right]^{\frac{1}{1-\epsilon_{h}}} .
$$

\subsection{Import goods retailers}

We allow for incomplete exchange rate pass-through into import prices in the short run (Medina and Soto, 2005). Thus, we consider a set of competitive assemblers that produce a final foreign-produced imported good, $Y_{f, t}$, which is consumed by households and also used for accumulating new capital goods. This set of competitive assemblers combine a continuum of differentiated imported varieties, $Y_{f, t}\left(z_{f}\right)$, sourced from import goods retailers. As in the case of domestic intermediate goods, the price of imported goods is determined à la Calvo (1983). Thus, an importing firm has a probability, $\theta_{f}$, of keeping the price of its good fixed in the next period and a probability, $1-\theta_{f}$, of optimally resetting its price. For a firm that can reset its price, the optimal reset price $\left(P_{f, t}^{\mathbf{R}}\right)$ is given by

$P_{f, t}^{\mathbf{v}}=\frac{\epsilon_{f}}{\epsilon_{f}-1} \frac{E_{t} \sum_{s=0}^{\infty}\left(\beta \theta_{f}\right)^{s} P_{f, t+s} Y_{f, t+s} \Psi_{t+s}}{E_{t} \sum_{s=0}^{\infty}\left(\beta \theta_{f}\right)^{s} Y_{f, t+s}}$

where the definition for the law of one price gap (equation 9) has been invoked in equation (16) and the parameter $\epsilon_{f}>1$ represents the elasticity of substitution among different imported goods.

\subsection{Oil producing firm}

The oil firm operates under perfect competition, combining an extraction technology $\left(A_{o, t}\right)$, materials sourced from the domestic economy $\left(M_{t}\right)$ and oil-related capital $\left(K_{o, t}\right)$ to produce oil output $\left(Y_{O, t}\right)$. The produced oil is exported to the rest of the world at a price determined in the international crude oil market. The firm maximises its profit subject to a constant return to scale Cobb-Douglas technology given by:

\footnotetext{
${ }^{9}$ We achieve this by introducing local currency pricing.
} 


$$
Y_{O, t}=A_{O, t} K_{O, t}^{\alpha_{o}^{k}} M_{t}^{\alpha_{O}^{m}}
$$

where the parameters $\alpha_{o}^{k} \in(0,1)$ and $\alpha_{o}^{m} \in(0,1)$ represent the elasticities of oil output with respect to oil-related capital and material inputs, respectively. Following Algozhina (2015), we assume that oilrelated capital, $K_{o, t}$ is accumulated via foreign direct investment, $F D I_{t}^{*}$, as follows: $\quad K_{o, t}=\left(1-\delta^{o}\right) K_{o, t-1}+F D I_{t}$, where $\delta^{o}$ represents the depreciation rate of oil-related capital. In turn, foreign direct investment responds to international oil price as follows:

$$
F D I_{t}^{*}=\left(F D I_{t-1}^{*}\right)^{\rho_{F D I}}\left(P_{o, t}^{*}\right)^{1-\rho_{f d i}},
$$

where $\rho_{f d i}$ measures the degree of smoothing in the accumulation of $F D I_{t}^{*}$ and $P_{o, t}^{*}$ is the international price of oil (in foreign currency) deflated by the foreign consumer price index. $P_{o, t}^{*}$ and $A_{o, t}$ are driven by $A R(1)$ processes with exogenous shocks as follows:

$$
P_{o, t}^{*}=\left(P_{o, t-1}^{*}\right)^{\rho_{o}} \exp \left(\varepsilon_{t}^{p_{o}^{*}}\right), \quad A_{o, t}=\left(A_{o, t-1}\right)^{\rho_{A_{o}}} \exp \left(\varepsilon_{t}^{A_{o}}\right)
$$

Finally, we assume that the oil firm is jointly owned by foreign direct investors and the government. Thus, it receives its profits net of royalties levied on production quantity at a rate $\tau^{o}$ as follows: $\Pi_{t}^{o *}=$ $\left(1-\tau^{o}\right) P_{o, t}^{*} Y_{o, t}$.

\subsection{Fiscal authority}

We assume the government respects a budget constraint given by

$$
T X_{t}+O R_{t}+B_{t}=P_{g, t} G_{c, t}+O S_{t}+\frac{B_{t+1}}{R_{t}} \text {. }
$$

Government's revenue sources include lump-sum tax, $T X_{t}$; oil revenues, $O R_{t}$; and issuance of one period bonds that results in a net debt position, $B_{t}$. On the expenditure side, government consumes public goods, $G_{c, t}$, at a price index, $P_{g, t}$, and makes subsidy payments, $O S_{t}$. The implicit subsidy expenditure results from an administrative decision by the government to regulate the domestic fuel price, $P_{r o, t}$. Since a substantial share of fuel consumed in the domestic economy is imported, we assume that the domestic price of imported fuel, $P_{r o, t}$, is regulated based on a fuel pricing rule given by ${ }^{10}$

$$
P_{r o, t}=\left(P_{r o, t-1}\right)^{(1-v)}\left(P_{l o, t}\right)^{v},
$$

${ }^{10}$ This follows Allegret and Benkhodja (2015) 
where $P_{l o, t}$ is the landing price of imported fuel and it is given by ${ }^{11}$

$$
P_{l o, t}=\epsilon_{t} \frac{P_{o, t}^{*}}{\Psi_{t}^{o}} .
$$

In equation (21), $P_{O, t}^{*}$ is the foreign currency price of oil abroad, $\epsilon_{t}$ is the nominal exchange rate and $\Psi_{t}^{o}$ is the law of one price gap associated with the import price of fuel. The evolution of $\Psi_{t}^{o}$ is assumed to follow an $A R(1)$ process with i.i.d innovations. In equation (20), the fuel pricing parameter $0<v<1$ measures the pass-through effect of oil prices into retail fuel price and governs the level of fuel subsidies. When $v=1$, there is full pass-through effect and the subsidy regime ceases to exist. On the other hand, $v=0$ implies complete price regulation. Thus, our simulations regarding fuel subsidy reforms are conducted based on different assumptions regarding the size of the fuel pricing parameter. The amount of fuel subsidy payment, $O S_{t}$, in our model is given by the difference between the total cost of imported fuel, $P_{l o, t} O_{t}$, (in domestic currency) and the amount realised from fuel sales in the domestic economy, $P_{r o, t} O_{t}$. Thus,

$$
O S_{t}=\left(P_{l o, t}-P_{r o, t}\right) O_{t},
$$

where $O_{t}$ denotes the total volume of imported fuel used up by households and firms. In our model, government consumption represents a key instrument of fiscal policy. Its evolution (in log-linearised form) is given by:

$\widetilde{G_{c, t}}=\rho_{g} \widetilde{G_{c, t-1}}+\left(1-\rho_{g}\right)\left[\omega_{y o} \widetilde{y_{o, t}}-\omega_{b} \widetilde{b_{t}}+\omega_{o r} \widetilde{\partial r_{t}}\right]+\varepsilon_{t}^{G_{c}}$,

where $\rho_{g}$ is the fiscal policy smoothing parameter, and $\omega_{y o}, \omega_{b}$ and $\omega_{o r}$ are government consumption feedback coefficients with respect to oil output, domestic debt and oil revenues, respectively. The feedback parameter with respect to oil output, $\omega_{y o}$, defines the cyclicality of government spending. A positive value for the feedback parameter on output $\left(\omega_{y o}>0\right)$ corresponds to pro-cyclical fiscal policy while a negative value $\left(\omega_{y o}<0\right)$ indicates counter-cyclical fiscal policy. Also, fiscal policy is acyclical when $\omega_{y o}>0$. The feedback parameter on debt, $\omega_{b}$ is assumed negative, implying that government current consumption declines with increased debt accumulation in the previous period. Consistent with the behaviour of most developing oil-rich countries, we

${ }^{11}$ This is similar to the specification in Poghosyan and Beidas-Strom (2011) 
assume that government consumption increases with increased oil revenues. Within this set-up, debt serves as a stabilising factor in the fiscal rule. The variables in tildes denote log deviations from their respective steady state values. We assume that the process for government spending shock, $\varepsilon_{t}^{G_{c}}$, is assumed i.i.d. The amount of oil revenue accruing to government is given by:

$$
O R_{t}=\tau^{o} \epsilon_{t} P_{O, t}^{*} Y_{O, t},
$$

where $\tau^{o}$ is the royalty rate on the quantity of oil production. Since the government budget constraint is cleared by fiscal debt, the equation for lump-sum taxes, $T X_{t}$, is written in log-linearised form as: $\widetilde{t x_{t}}=\varphi_{b} \widetilde{b_{t-1}}+$ $\varphi_{g} \widetilde{g_{c, t}}+\varphi_{o s} \widetilde{O s_{t}}-\varphi_{o r} \widetilde{O r_{t}}$. The parameters $\varphi_{b}, \varphi_{g}, \varphi_{o s}$ and $\varphi_{o r}$ represent the responses of lump-sum tax to fiscal debt, government consumption, fuel subsidy payments and oil revenue, respectively.

\subsection{Monetary authority}

In setting the short-term nominal interest rate $\left(R_{t}\right)$, the central bank follows a simple Taylor by gradually responding to aggregate inflation $\left(\pi_{t}\right)$, domestic output $\left(y_{h, t}\right)$, and real exchange rate $\left(s_{t}\right)$ as follows:

$\widetilde{R_{t}}=\rho_{r} \widetilde{R_{t-1}}+\left(1-\rho_{r}\right)\left[\omega_{\pi} \widetilde{\pi_{t}}+\omega_{y} \widetilde{y_{h, t}}+\omega_{s} \widetilde{s_{t}}\right]+\varepsilon_{t}^{r}$,

with the variables in tildes denoting log deviations from their respective steady state values while inflation is log-difference in aggregate consumer price index. The interest rate smoothing parameter is denoted by $\rho_{r}$, while $\omega_{\pi}, \omega_{y}$ and $\omega_{s}$ are the feedback coefficients on inflation, output and real exchange rate, respectively. The monetary policy shock, $\varepsilon_{t}^{r}$, is assumed to follow an i.i.d process.

\subsection{Market clearing and aggregation}

Domestic non-oil output $\left(Y_{h, t}\right)$ is absorbed by domestic consumption (comprising households - $C_{h, t}$, oil producing firms - $M_{t}$, and government - $\left.G_{h, t}\right)$; non-oil exports $\left(C_{h, t}^{*}\right)$; and domestic investment $\left(I_{h, t}\right)^{12}$. Consequently, the domestic resource constraint in real terms is given by: $Y_{h, t}=C_{h, t}+C_{h, t}^{*}+M_{t}+I_{h, t}+G_{h, t}$. On the other hand, aggregate real gross domestic product (GDP) comprises of both oil $\left(Y_{o, t}\right)$ and non-oil output $\left(Y_{h, t}\right)$. This is given by:

\footnotetext{
${ }^{12}$ Which is used to augment the stock of physical capital available for use in the production process in period $t+1$
} 


$$
Y_{t}=Y_{h, t}+Y_{o, t}=C_{h, t}+M_{t}+I_{h, t}+G_{h, t}+n x_{t} .
$$

Real net exports $\left(n x_{t}\right)$ represents the difference between total exports $\left(e x_{t}\right)$ and imports $\left(i m_{t}\right): n x_{t}=e x_{t}-i m_{t}$. The balance of payments (BOP) equation is given by

$\frac{s_{t} B_{t}^{*}}{R_{t}^{*}}=s_{t} B_{t-1}^{*}+n x_{t}-\left(1-\tau^{o}\right) s_{t} P_{O, t}^{*} Y_{O, t}+s_{t} F D I_{t}^{*}$.

while the labour and capital markets clear as follows:

$$
N_{t}=\int_{0}^{1} N_{t}^{R}(j) d j+\int_{0}^{1} N_{t}^{N R}(j) d j, \quad K_{H, t}=\int_{0}^{1} K_{H, t}(j) d j .
$$

\subsection{Rest of the world}

The demand for domestic goods by the foreign economy, $C_{h, t}^{*}$, is given by:

$$
C_{h, t}^{*}=\gamma^{*} \frac{P_{h, t}^{*} \eta^{*}}{P_{t}^{*}} C_{t}^{*}
$$

where $P_{h, t}^{*}$ is the price of domestic goods in foreign currency, $P_{t}^{*}$ is the aggregate consumer price index in the foreign economy, and $C_{t}^{*}$ is aggregate foreign consumption. The parameter, $\eta^{*}$, represents the foreign price elasticity of demand for domestic goods while the share of domestic goods in foreign consumption is captured by $\gamma^{*}$. The IS curve for the foreign economy is specified as:

$$
\frac{1}{R_{t}^{*} \mu_{t}^{*}}=\beta E_{t}\left[\left(\frac{C_{t+1}^{*}(j)-\phi_{c}^{*} C_{t}^{*}}{C_{t}^{*}(j)-\phi_{c}^{*} C_{t-1}^{*}}\right)^{-\sigma_{c}^{*}} \frac{1}{\pi_{t+1}^{*}}\right],
$$

where $\phi_{c}^{*}$ is the habit formation parameter in the foreign economy and $\sigma_{c}^{*}$ is the relative risk aversion coefficient. The variables $C_{t}^{*}, R_{t}^{*}$ and $\pi_{t}^{*}$ represent consumption, interest rate and inflation rate in the foreign economy. The central bank in the foreign economy sets interest rate in a similar fashion as the domestic economy by following a Taylor rule given by

$$
R_{t}^{*}=\left(R_{t-1}^{*}\right)^{\rho_{r^{*}}}\left[\left(\pi_{t}^{*}\right)^{\omega_{\pi^{*}}}\left(Y_{h, t}^{*}\right)^{\omega_{y^{*}}}\right]^{1-\rho_{r^{*}}} \exp \left(\varepsilon_{t}^{r^{*}}\right),
$$

where $\rho_{r^{*}}$ represents the interest rate smoothing parameter in the foreign economy while $\omega_{\pi^{*}}$ and $\omega_{y^{*}}$ are the feedback coefficients with respect to 
inflation and output, respectively. The shock to foreign monetary policy is represented by $\varepsilon_{t}^{\pi^{*}}$. Finally, inflation rate in the foreign economy is assumed to be given by:

$$
\pi_{t}^{*}=\left(\pi_{t-1}^{*}\right)^{\rho_{\pi^{*}}} \exp \left(\varepsilon_{t}^{\pi^{*}}\right)
$$

where $\rho_{\pi^{*}}$ is the persistence parameter for foreign inflation and $\varepsilon_{t}^{\pi^{*}}$ is the corresponding shock.

\subsection{Model Estimation and Data}

The model is estimated via Bayesian methodology outlined in Schorfheide (2000). To do this, we solve a system of log-linear rational expectations equations of our model and express the solution as a vector autoregressive representation (VAR) in $z_{t}$ :

$$
z_{t}=\Gamma_{1}(\Omega) z_{t-1}+\Gamma_{2}(\Omega) \epsilon_{t},
$$

where the coefficient matrices $\Gamma_{1}(\Omega)$ and $\Gamma_{2}(\Omega)$ are non-linear functions of the structural parameters of our model. Next, measurement equations are added in order to link the observable variables to the vector of state variables, $z_{t}$. The measurement equation is written as:

$$
g_{t}=H z_{t},
$$

where $g_{t}$ is a vector of observables that is of a lower dimension than $z_{t}$ and $H$ is a selection matrix. In our proposed model, the vector of observable variables is

$$
g_{t} \equiv\left[y_{t}^{o b s}, c_{t}^{o b s}, i_{t}^{o b s}, s_{t}^{o b s}, P_{t}^{o b s}, P_{n o, t}^{o b s}, R_{t}^{o b s} y_{t}^{* o b s}, P_{t}^{* o b s}, R_{t}^{* o b s}, P_{o, t}^{* o b s}\right]^{\prime},
$$

while the remaining variables are considered unobserved. Based on equation (28), we construct the likelihood function for the structural parameters via Kalman Filter ${ }^{13}$. The likelihood density is then combined with the prior distribution of the parameters in order to obtain the posterior density function. In the final step, the posterior distribution of the parameters is derived numerically based on Metropolis-Hastings Monte Carlo Markov Chain (MCMC) algorithm. We then simulate 3 million draws from the random walk Metropolis-Hastings, discarding 30 per cent of the first draws as burn-in.

\footnotetext{
${ }^{13}$ This is computed under the assumption of normally distributed disturbances.
} 
The model is fitted to the datasets on eleven macroeconomic variables covering the period 2000Q2 - 2018Q2 ${ }^{14}$. These are headline Consumer Price Index $\left(P_{t}^{o b s}\right)$, core CPI $\left(P_{n o, t}^{o b s}\right)$, nominal interest rate $\left(R_{t}^{o b s}\right)$, real effective exchange rate $\left(s_{t}^{o b s}\right)$, real GDP per capita $\left(y_{t}^{o b s}\right)$, real consumption per capita $\left(c_{t}^{o b s}\right)$, real investment per capita $\left(i_{t}^{o b s}\right)$, the international price of oil $\left(P_{o, t}^{* o b s}\right)$ deflated by foreign price index, tradeweighted foreign real GDP per capita $\left(y_{t}^{* o b s}\right)$, trade-weighted foreign aggregate CPI $\left(P_{t}^{* o b s}\right)$, and trade-weighted foreign interest rate $\left(R_{t}^{* o b s}\right)$. The foreign variables are weighted based on Nigeria's trade with her major trading partners: the Euro area, the United States, and India ${ }^{15}$. Dataset on the domestic variables are sourced from the National Bureau of Statistics (NBS) and the Central Bank of Nigeria (CBN) statistics database. In order to derive per capita values for relevant domestic variables, we used the annual population figures to interpolate for the quarters. The data set for foreign variables as well as the international price of oil $\left(P_{o, t}^{* o b s}\right)$ are retrieved from the Federal Reserve Bank of St. Louis database (FRED) and the International Financial Statistics (IFS) of the International Monetary Fund (IMF). With the exception of interest rates, we transform the observables to their model consistent forms by taking their log-differences. The interest rates are, however, expressed in quarterly terms.

\subsection{Model parameters}

\subsubsection{Parametrization}

Table 2 presents a list of calibrated parameters and their values. These parameters are derived from relevant sources, including typical values assumed for small open economies as in Gali and Monacelli (2005) and resource-rich emerging economies such as Romero (2008), Ferrero and Seneca (2019), Iklaga (2017), and Omotosho (2019).

We set the discount factor, $\beta$, equal to 0.99 (Allegret and Benkhodja, 2015; Iklaga, 2017); the depreciation rate, $\delta^{h}$, equal to 0.025 (Algozhina, 2015; Allegret and Benkhodja, 2015; Iklaga, 2017); share of imports in household's consumption, $\gamma_{C}$, equal to 0.4 (Gali and Monacelli, 2005);

\footnotetext{
${ }^{14}$ The choice of the estimation sample is largely influenced by data availability for the domestic economy.

${ }^{15}$ These three regions account for about 65 per cent of Nigeria's total external trade over the last two decades. The normalised trade weights are: the Euro area (0.39), United States (0.36), and India (0.25), respectively.
} 
share of imports in household's investment, $\gamma_{I}$, equal to 0.2 ; elasticity of domestic output with respect to capital, $\alpha_{h}^{k}$, equal to 0.33 (Algozhina, 2015; Rasaki and Malikane, 2015); elasticity of domestic output with respect to labour, $\alpha_{h}^{n}$, equal to 0.55 (Ncube and Balma, 2017); elasticity of oil output with respect to capital, $\alpha_{o}^{k}$, equal to 0.7 (Algozhina, 2015); elasticity of oil output with respect to materials, $\alpha_{o}^{m}$, equal to 0.3 (Algozhina, 2015; Ferrero and Seneca, 2019). Most of the parameters relating to fiscal policy and the fuel pricing rule are based on Algozhina (2015).

Table 2: Calibrated parameters

\begin{tabular}{|c|c|c|}
\hline Parameter Definition & Symbol & Value \\
\hline Discount factor & $\beta$ & 0.990 \\
\hline Depreciation rate & $\delta^{h}=\delta^{o}$ & 0.025 \\
\hline Share of imports in household's consumption & $\gamma_{c}$ & 0.400 \\
\hline Share of fuel in household's consumption & $\gamma_{o}$ & 0.085 \\
\hline Share of imports in household's investment & $\gamma_{i}$ & 0.200 \\
\hline Relative initial conditions in asset holdings & $\varrho$ & 1.000 \\
\hline Calvo - wages & $\theta_{w}$ & 0.750 \\
\hline Elasticity of domestic output with respect to capital & $\alpha_{h}^{k}$ & 0.330 \\
\hline Elasticity of domestic output with respect to oil & $\alpha_{h}^{o}$ & 0.120 \\
\hline Elasticity of domestic output with respect to labour & $\alpha_{h}^{n}$ & 0.550 \\
\hline Elasticity of oil output with respect to capital & $\alpha_{o}^{k}$ & 0.700 \\
\hline Elasticity of oil output with respect to materials & $\alpha_{o}^{m}$ & 0.300 \\
\hline Share of imports in government's consumption & $\gamma_{g}$ & 0.120 \\
\hline Elasticity of sub. between foreign \& domestic goods - Govt & $\eta_{g}$ & 0.600 \\
\hline Response of public consumption to fiscal debt & $\omega_{b}$ & 0.300 \\
\hline Response of public consumption to oil revenue & $\omega_{\text {or }}$ & 0.800 \\
\hline Response of lump-sum taxes to fiscal debt & $\varphi_{b}$ & 0.400 \\
\hline Response of lump-sum taxes to government consumption & $\varphi_{g}$ & 0.950 \\
\hline Response of lump-sum taxes to fuel subsidy payments & $\varphi_{o s}$ & 0.100 \\
\hline Response of lump-sum taxes to oil revenue & $\varphi_{\text {or }}$ & 0.300 \\
\hline Habit formation parameter in foreign economy & $\phi_{c}^{*}$ & 0.000 \\
\hline Intra-temporal elasticity in foreign demand & $\eta^{*}$ & 0.790 \\
\hline Relative risk aversion coefficient in the foreign economy & $\sigma_{c}^{*}$ & 1.000 \\
\hline Coefficient of inflation in Taylor Rule - foreign economy & $\omega_{\pi^{*}}$ & 1.500 \\
\hline Coefficient of output in Taylor Rule - foreign economy & $\omega_{y^{*}}$ & 0.500 \\
\hline \multicolumn{3}{|l|}{ Implied steady state ratios } \\
\hline Consumption - output & $C_{h} / Y_{h}$ & 0.690 \\
\hline Investment - output & $I_{n o} / Y_{h}$ & 0.150 \\
\hline Domestic materials - output & $M / Y_{h}$ & 0.010 \\
\hline Government consumption - output & $G_{c} / Y_{h}$ & 0.070 \\
\hline Export - output & $C_{h}^{*} / Y_{h}$ & 0.070 \\
\hline Import - output & $I M / Y_{h}$ & 0.150 \\
\hline
\end{tabular}

\subsubsection{Prior moments}

Our assumptions regarding the prior distributions of the estimated parameters are presented in Table 3. The priors for the domestic economy are chosen based on calibration, the data and partly on Iklaga (2017). On the other hand, the foreign priors are based on Smets and Wouters (2007). In cases where we have limited information to form a credible prior, we impose less informative priors, allowing the data to determine the location of the parameter. As in Smets and Wouters (2007), we set the 
Omotosho

autoregressive coefficients for the exogenous disturbances uniformly to follow beta distributions centered at 0.5. However, we assume larger standard deviations of 0.25 in order to reflect our level of uncertainty about the assumed parameter values. In terms of the parameters of the shock processes, we assume an inverse gamma distribution with a mean of 0.10 and a standard deviation of 4.0, which is much higher than 2.0 in Smets and Wouters (2007).

We assume that the proportion of Ricardian consumers $\left(\gamma_{R}\right)$ is represented by a beta distribution with a mean of 0.6 and standard deviation of 0.10 (Iklaga, 2017; Ncube and Balma, 2017). The labour supply elasticity $(\varphi)$ is set to 1.45 in line with Algozhina (2015) and assumed to follow a gamma distribution with a standard deviation of 0.1. The risk aversion parameter, $\sigma$, is represented by an inverse gamma distribution with a mean of 2.0 (Iklaga, 2017). The external habit parameter $\left(\emptyset_{c}\right)$ is represented by a beta distribution with a mean of 0.7 and standard deviation of 0.1 (Iklaga, 2017) while the investment adjustment cost parameter $(\chi)$ is represented by a gamma distribution with mean 4.0 and a relatively large standard deviation of 3.0 (Iklaga, 2017; Ncube and Balma, 2017).

The reaction coefficients in the monetary policy function are assumed to follow gamma distributions with the coefficient for inflation $\left(\omega_{\pi}\right)$ centered at 1.5 while the coefficients for output $\left(\omega_{y}\right)$ and exchange rate $\left(\omega_{s}\right)$ are each set to 0.125 (Adebiyi and Mordi, 2016; Iklaga, 2017; Smets and Wouters, 2007). The fuel pricing parameter, $v$, is set to follow a beta distribution with a mean of 0.3 in line with Allegret and Benkhodja (2015). At $v=0.3$, we assume a pass-through effect of 30 per cent from international oil prices into retail fuel price.

\subsection{Results}

In this section, we present the posterior distributions of the estimated parameters and analyse the effects of oil price shocks on the Nigerian economy. We also show the results of our counterfactual simulations regarding the responses of the economy to an oil price shock under alternative assumptions regarding the pass-through effects of oil prices into domestic price of fuel. 


\subsection{Posterior estimates}

Table 3 reports the posterior moments for the estimated structural, policy and shock parameters. The parameters in the utility function are estimated to be lower than their priors. For instance, at $\sigma=1.4$, the estimated relative risk aversion parameter is lower than 2.0 initially assumed but slightly higher than 1.38 estimated by Smets and Wouters (2007) for the US economy. This implies that the savings/investment behaviour of households are more sensitive to structural shocks in Nigeria.

Table 3: Priors and posterior estimates

\begin{tabular}{|c|c|c|c|c|c|}
\hline \multirow[b]{2}{*}{ Parameter } & \multicolumn{3}{|c|}{ Prior distribution } & \multicolumn{2}{|c|}{ Posterior distribution } \\
\hline & Density & Mean & $\begin{array}{l}\text { Std. } \\
\text { Dev. }\end{array}$ & Mean & 90\% HPD Int. \\
\hline \multicolumn{6}{|l|}{ Structural parameters } \\
\hline Ricardian consumers: $\gamma_{R}$ & Beta & 0.60 & 0.10 & 0.692 & $0.562-0.824$ \\
\hline Labour supply elasticity: $\varphi$ & Gamma & 1.45 & 0.10 & 1.439 & $1.274-1.600$ \\
\hline Relative risk aversion: $\sigma$ & Inv. Gamma & 2.00 & 0.40 & 1.409 & $1.109-1.694$ \\
\hline External habit: $\phi_{c}$ & Beta & 0.70 & 0.10 & 0.438 & $0.310-0.568$ \\
\hline Investment adj. cost: $\chi$ & Gamma & 4.00 & 3.00 & 6.181 & $1.751-10.490$ \\
\hline Fuel pricing parameter: $v$ & Beta & 0.30 & 0.10 & 0.429 & $0.190-0.640$ \\
\hline Oil - core cons. elasticity: $\eta_{o}$ & Gamma & 0.20 & 0.10 & 0.188 & $0.044-0.328$ \\
\hline For. - dom. cons. elasticity: $\eta_{c}$ & Gamma & 0.60 & 0.20 & 0.609 & $0.287-0.926$ \\
\hline For. - dom. inv. elasticity: $\eta_{i}$ & Gamma & 0.60 & 0.20 & 0.615 & $0.286-0.933$ \\
\hline Calvo - domestic goods: $\theta_{h}$ & Beta & 0.70 & 0.10 & 0.719 & $0.620-0.826$ \\
\hline Calvo - imported goods: $\theta_{f}$ & Beta & 0.70 & 0.10 & 0.691 & $0.525-0.860$ \\
\hline \multicolumn{6}{|l|}{ Policy parameters } \\
\hline Taylor rule - inflation: $\omega_{\pi}$ & Gamma & 1.500 & 0.20 & 2.857 & $2.579-3.141$ \\
\hline Taylor rule - output: $\omega_{y}$ & Gamma & 0.125 & 0.05 & 0.118 & $0.043-0.191$ \\
\hline Taylor rule - exch. rate: $\omega_{s}$ & Gamma & 0.125 & 0.05 & 0.109 & $0.040-0.176$ \\
\hline Interest rate smoothing: $\rho_{r}$ & Beta & 0.500 & 0.25 & 0.224 & $0.054-0.382$ \\
\hline Fiscal policy cyclicality: $\omega_{y o}$ & Normal & 0.400 & 0.50 & 0.351 & $-0.47-1.184$ \\
\hline Fiscal policy persistence: $\rho_{g}$ & Beta & 0.500 & 0.25 & 0.487 & $0.073-0.896$ \\
\hline \multicolumn{6}{|l|}{ Persistence of shocks } \\
\hline Dom. productivity: $\rho_{a_{h}}$ & Beta & 0.5 & 0.25 & 0.771 & $0.593-0.957$ \\
\hline Oil productivity: $\rho_{a_{0}}$ & Beta & 0.5 & 0.25 & 0.502 & $0.100-0.905$ \\
\hline Dom. risk premium: $\rho_{\mu}$ & Beta & 0.5 & 0.25 & 0.786 & $0.703-0.871$ \\
\hline Law of one price gap-oil: $\rho_{\psi^{o}}$ & Beta & 0.5 & 0.25 & 0.608 & $0.250-0.957$ \\
\hline Int'l oil price shock: $\rho_{p_{o}}$ & Beta & 0.5 & 0.25 & 0.923 & $0.827-0.987$ \\
\hline For. risk premium: $\rho_{\mu^{*}}$ & Beta & 0.5 & 0.25 & 0.859 & $0.790-0.929$ \\
\hline For. inflation: $\rho_{\pi^{*}}$ & Beta & 0.4 & 0.25 & 0.138 & $0.001-0.257$ \\
\hline For. monetary policy: $\rho_{r^{*}}$ & Beta & 0.5 & 0.25 & 0.442 & $0.303-0.584$ \\
\hline \multicolumn{6}{|l|}{ Standard deviation of shocks } \\
\hline Dom. productivity: $\varepsilon_{t}^{a_{h}}$ & Inv. Gamma & 0.1 & 4 & 0.246 & $0.105-0.407$ \\
\hline Oil productivity: $\varepsilon_{t}^{a_{o}}$ & Inv. Gamma & 0.1 & 4 & 0.076 & $0.024-0.133$ \\
\hline Dom. risk premium: $\varepsilon_{t}^{\mu}$ & Inv. Gamma & 0.1 & 4 & 0.162 & $0.132-0.192$ \\
\hline Dom. fiscal policy: $\varepsilon_{t}^{g_{c}}$ & Inv. Gamma & 0.1 & 4 & 0.098 & $0.023-0.177$ \\
\hline Law of one price gap-oil: $\varepsilon_{t}^{\psi^{o}}$ & Inv. Gamma & 0.1 & 4 & 0.904 & $0.444-1.490$ \\
\hline Dom. monetary policy: $\varepsilon_{t}^{r}$ & Inv. Gamma & 0.1 & 4 & 0.379 & $0.300-0.455$ \\
\hline
\end{tabular}

The estimated labour supply elasticity ( $\varphi=1.44)$ is about the same value as its assumed prior of 1.45 while the estimated external habit parameter $\left(\emptyset_{c}\right)$ is 0.4 , which is lower than the assumed prior of 0.7 . The posterior 
mean for the share of Ricardian consumers $\left(\gamma_{R}\right)$ is 0.69 . This is higher than the estimate of 0.62 obtained by Iklaga (2017) for the period 20032015. The estimated Taylor rule indicates that the Central Bank of Nigeria (CBN) has been quite hawkish while also keeping an eye on output and the exchange rate. The CBN's reaction coefficient on inflation $\left(\omega_{\pi}\right)$ is estimated at 2.86, which is substantially higher than the prior (1.50), the 1.45 obtained by Iklaga (2017) and 1.405 estimated for an oil-importing economy of South Africa by Hollander et al. (2018). At $\omega_{y}=0.12$, output considerations carry a higher weight in the Taylor rule than exchange rate $\left(\omega_{s}=0.11\right)$. The estimated interest rate smoothing parameter is low $\left(\rho_{r}=0.22\right)$, but comparable to the value of 0.21 obtained by Olayeni and Olabode (2013) for Nigeria over the period 1986-2004 and 0.26 obtained by Medina and Soto (2005) for the Chilean economy. The observed policy behaviour of the CBN is consistent with the findings of Olayeni and Olabode (2013) and Adebiyi and Mordi (2016).

In terms of fiscal policy, our results provide evidence of pro-cyclical fiscal policy as the feedback parameter with respect to oil output $\left(\omega_{y o}\right)$ in the government spending rule is estimated at 0.35 . Also, the fiscal policy persistence parameter is estimated at 0.49 , which is slightly lower than the assumed prior of 0.5 .

Turning to the fuel pricing rule, which governs the dynamics of the fuel consumption subsidy regime, our results show that the government bears more than half of the effects of international oil prices on domestic fuel price under its subsidy programme. The estimated pass-through parameter $(v)$ is 0.43 , which is higher than the value of 0.30 initially assumed. This implies an incomplete pass-through of international oil prices into domestic fuel price, as expected of an economy with a fuel subsidy programme. This effort appears to be the first attempt at estimating this parameter for Nigeria. As earlier explained, our counterfactual simulations shown in sub-section 4.3 are based on alternative assumptions regarding the pass-through parameter in the domestic fuel pricing rule. Our benchmark simulation corresponds to the estimated value of the passthrough parameter $(v=0.43)$ while the alternative scenario is based on a value of unity, implying complete pass-through of oil price shocks into retail fuel price. 


\subsection{How important are oil price shocks?}

\subsubsection{Historical decomposition}

In this sub-section, we analyse the historical decompositions of aggregate GDP, headline inflation, core inflation, real exchange rate and the interest rate over the sample period. For ease of presentation and analysis, we group the shocks under five categories: (i) oil shocks (comprising oil sector productivity, international oil price, and the law of one price gap for fuel); (ii) external shocks (comprising foreign inflation, foreign interest rate and external risk premium); (iii) domestic supply shocks (comprising domestic productivity and domestic risk premium); (iv) monetary policy shock; and (v) fiscal policy shock.

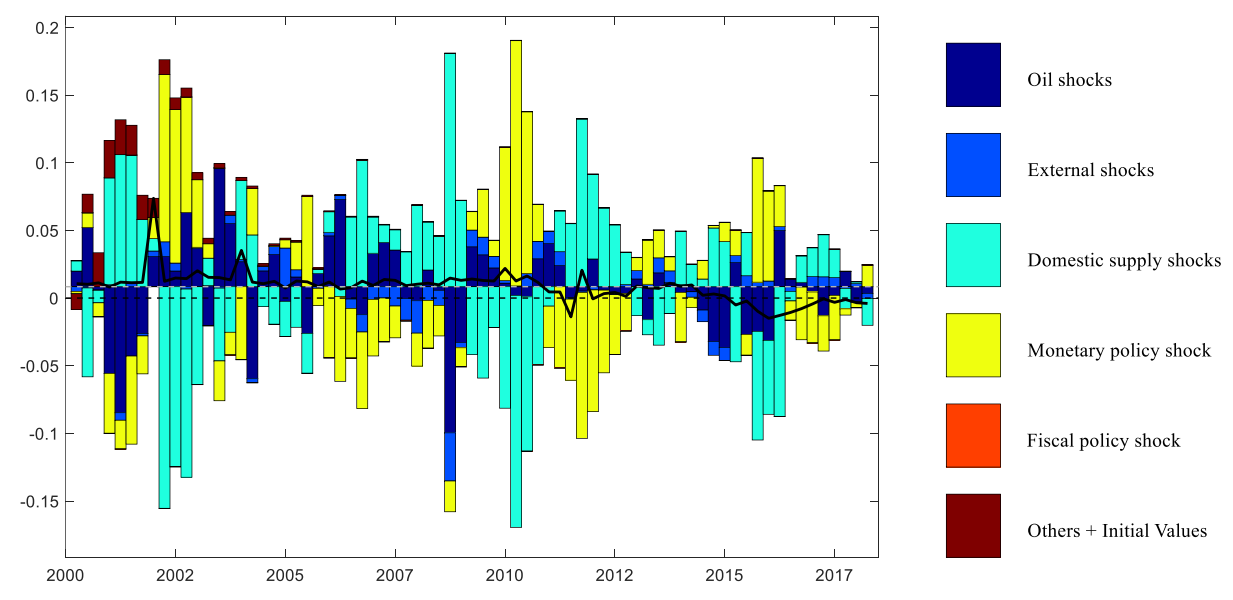

Figure 1: Historical decomposition of output

Figure 1 presents the historical decomposition of the five groups of shocks to the growth of aggregate GDP during the period 2000Q2-2018Q2. The improved output performances in the second half of years 2001 and 2005 were driven largely by positive oil shocks, a dovish monetary policy stance, and positive domestic supply shocks. We also observe that the second half of the last decade (2005 - 2010) was associated with relative stability in output growth with monetary policy shocks, domestic supply shocks and oil shocks playing significant roles. However, the poor output performance recorded in the third quarter of 2011 can be explained by negative domestic supply shocks as well as the hawkish stance of monetary policy in response to the inflationary pressures that resulted from the impacts of the 2008/09 global financial crisis. It is also clear from Figure 1 that negative oil and domestic supply shocks were the predominant sources of the negative output growth recorded in 2016. 
Omotosho

Figure 2 presents the historical decomposition of aggregate inflation. Oil shocks played prominent roles in the last decade (2000-2010) while monetary and domestic supply shocks are more relevant in the current decade. The observed inflationary pressures during the mid-2000s were driven by negative domestic supply shocks. Also, the increasing inflationary trend experienced during the second half of 2015 are attributable to negative domestic supply and monetary policy shocks.

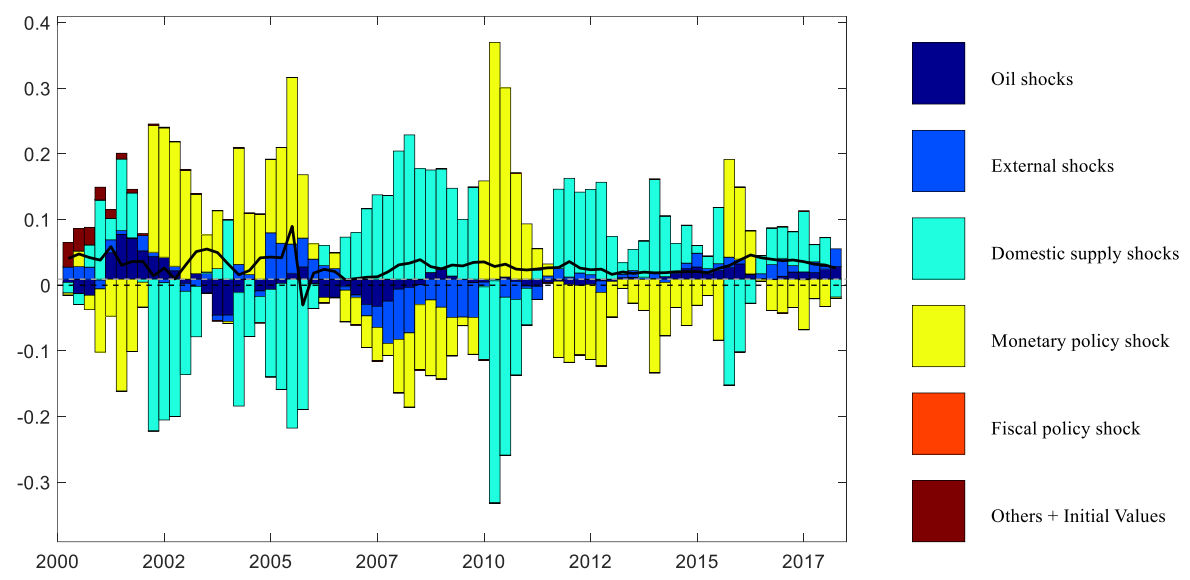

Figure 2: Historical decomposition of headline inflation

Figure 3 shows that oil shocks as well as monetary policy innovations played non-trivial roles in the evolution of real exchange rate during the sample period. Prior to the 2008/09 global financial crisis, the exchange rate exhibited high volatility, which is mainly attributable to oil shocks and domestic supply shocks (i.e. total factor productivity). The sharp depreciation recorded during the global financial crisis was subsequently met with higher oil prices and monetary policy tightening by the Central Bank of Nigeria. Thus, a combination of favourable oil prices and positive monetary policy innovations explained the appreciation of the exchange rate between 2009 and 2010. Subsequently, the exchange rate remained relatively stable till the first half of 2015 when a sharp depreciation was again recorded, owing to oil shocks, domestic supply innovations and external shocks. 


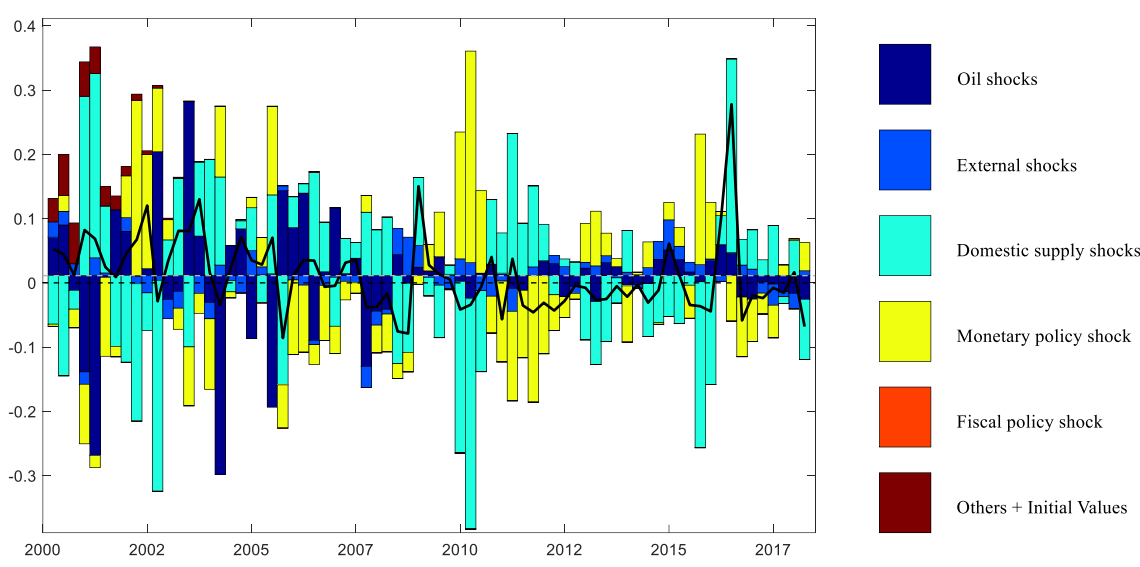

Figure 3: Historical decomposition of real exchange rate

The massive depreciation in the exchange rate in the period 2015-17 is principally explained by domestic supply shocks and oil-related disturbances. During this period, the oil price crashed from about US\$102/barrel in the third quarter of 2014 to about US\$50/barrel in the second quarter of 2017. This sort of significant crash generates non-trivial effects on general economic activities of a resource-rich, resourcedependent country, such as Nigeria. The massive reduction in oil earnings during 2015-17 led to scarcity of foreign exchange, which led to a rapid depletion in Nigeria's stock of external reserves. Faced with a near currency crisis situation, the CBN devalued the domestic currency (Naira) and restricted selected importers' access to the official foreign exchange supply. Consequently, domestic producers were unable to effectively source for foreign exchange to meet their import needs for raw materials and machineries, causing a negative shock to domestic factor productivity. The massive depreciation was then followed by a correction in the exchange rate and some stability in the foreign exchange market, owing to a rebound in the price of crude oil in the third quarter of 2017 as well as a hawkish monetary policy stance of the $\mathrm{CBN}$ during the period. 


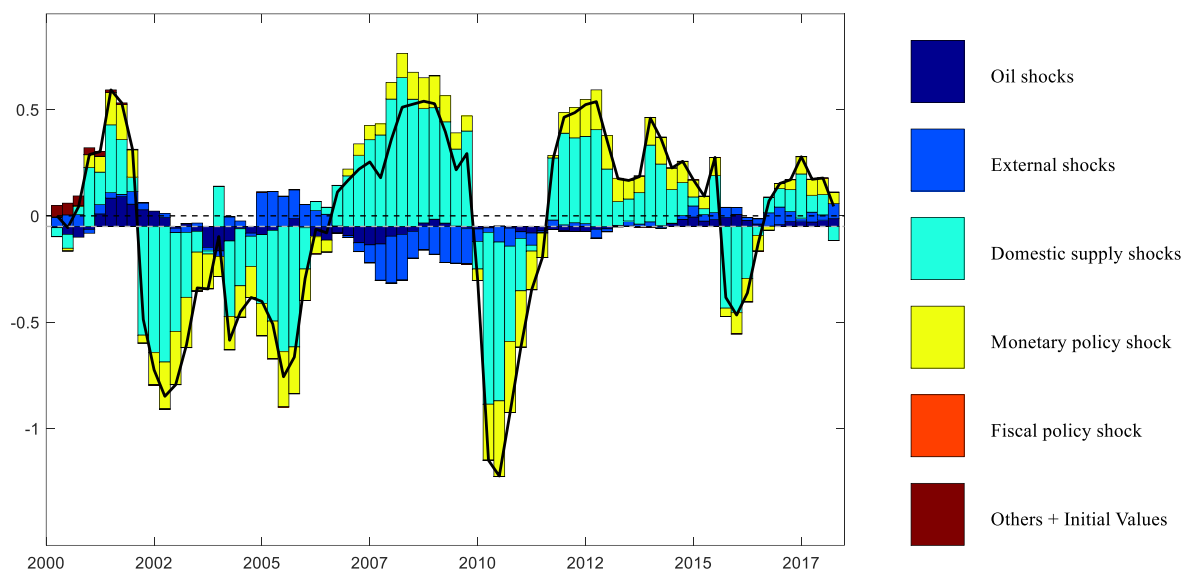

Figure 4: Historical decomposition of interest rate

Finally, the historical decomposition of interest rate over the sample period is shown in Figure 4. Similar to the findings of Hollander et al. (2018) for the South-African economy, our results indicate that monetary policy and domestic supply (largely risk premium) shocks play non-trivial roles in the evolution of the nominal interest rate in Nigeria. Also, external shocks (i.e. foreign inflation and external risk premium shocks) play relatively significant roles in explaining the hawkish monetary policy stance of the CBN during the period of the global financial crisis.

\subsubsection{Forecast error variance decomposition}

In Table 4, we present the forecast error variance decompositions of aggregate output and the headline inflation over four different time horizons. We have maintained the grouping of the shocks as in sub-section 4.2.1.

Table 4 shows that domestic supply shocks contribute about 46.4 per cent to variations in aggregate output within the first year (4 quarters). It is clear from the results that the effects of domestic supply shocks on output are quite persistent; it contributed up to 56.42 per cent to its variations by the fourth year. In the short run, monetary policy constitutes the second most dominant shock, accounting for 29.5 per cent of output variations. Also, about a fifth of total variations in GDP is caused by oil shocks over the one-to-four year horizons. By the third and fourth years, oil shocks constitute the second most dominant shock driving the variations in aggregate GDP. 
Table 4: Forecast error variance decomposition of selected variables

\begin{tabular}{|c|c|c|c|c|}
\hline Shock & 4 quarters & $\begin{array}{c}8 \\
\text { quarters }\end{array}$ & $\begin{array}{c}12 \\
\text { quarters }\end{array}$ & $\begin{array}{c}16 \\
\text { quarters }\end{array}$ \\
\hline \multicolumn{5}{|c|}{ Variance decomposition of aggregate GDP (\% contribution) } \\
\hline Domestic supply shocks & 46.43 & 55.80 & 56.76 & 56.42 \\
\hline External shocks & 2.42 & 1.95 & 1.84 & 1.81 \\
\hline Oil shocks & 21.73 & 20.04 & 20.65 & 21.58 \\
\hline Monetary policy shocks & 29.46 & 21.95 & 20.50 & 19.95 \\
\hline Fiscal policy shocks & 0.33 & 0.25 & 0.25 & 0.24 \\
\hline \multicolumn{5}{|c|}{ Variance decomposition of headline inflation (\% contribution) } \\
\hline Domestic supply shocks & 31.54 & 34.50 & 35.07 & 35.16 \\
\hline External shocks & 26.39 & 25.22 & 24.98 & 24.92 \\
\hline Oil shocks & 1.60 & 1.79 & 1.86 & 1.94 \\
\hline Monetary policy shocks & 40.46 & 38.48 & 38.09 & 37.97 \\
\hline Fiscal policy shocks & 0.00 & 0.00 & 0.00 & 0.00 \\
\hline \multicolumn{5}{|c|}{ Variance decomposition of real exchange rate (\% contribution) } \\
\hline Domestic supply shocks & 48.23 & 51.54 & 51.19 & 50.90 \\
\hline External shocks & 16.56 & 15.41 & 15.13 & 14.86 \\
\hline Oil shocks & 17.30 & 17.91 & 19.11 & 19.96 \\
\hline Monetary policy shocks & 17.76 & 15.04 & 14.48 & 14.20 \\
\hline Fiscal policy shocks & 0.14 & 0.08 & 0.09 & 0.09 \\
\hline \multicolumn{5}{|c|}{ Variance decomposition of interest rate (\% contribution) } \\
\hline Domestic supply shocks & 59.87 & 63.48 & 64.11 & 64.21 \\
\hline External shocks & 32.37 & 29.26 & 28.72 & 28.60 \\
\hline Oil shocks & 1.55 & 1.65 & 1.67 & 1.70 \\
\hline Monetary policy shocks & 6.21 & 5.60 & 5.49 & 5.47 \\
\hline Fiscal policy shocks & 0.00 & 0.00 & 0.00 & 0.01 \\
\hline
\end{tabular}

Headline inflation is largely driven by monetary policy shocks, confirming the efficacy of monetary policy in curbing inflationary tendencies in the country. The second most important shocks relate to domestic supply as they account for about a third of total variations in headline inflation across the different time horizons considered. As expected of a small open economy developed in this paper, external shocks account for about 26.4 per cent variations in the short-run and up to about 24.9 per cent by the fourth year. Expectedly, the contribution of oil price shocks to headline inflation is quite miniscule, perhaps owing to the incomplete pass-through of international oil prices into domestic fuel price.

Our results show that domestic supply shocks (total factor productivity and domestic risk premium) account for about 50.9 per cent of the total variation in real exchange rate over the 1-4 year horizon. However, in the first year, external shocks (foreign inflation, foreign interest rate and external risk premium shocks) and monetary policy innovations jointly explain about 34.32 per cent of its variation. Also, oil shocks account for a relatively substantial part of total variations in exchange rate over the 
horizons considered, ranging from 17.3 per cent in the first year to about 20.0 per cent up to the fourth year. By the fourth year, oil price shock is the second largest category of shock explaining the variations in exchange rate, after domestic shocks. Furthermore, our results show that domestic supply and external shocks are the key drivers of nominal interest rates, jointly accounting for over 90.0 per cent of the forecast variance across all the horizons considered. However, fiscal policy and oil price shocks contribute in a relatively negligible way.

\subsection{Oil price shocks, fuel subsidy and the economy \\ 4.3.1 Response of the economy to a negative oil price shock}

Figure 5 shows the estimated impulse responses of selected model variables to a one standard deviation (one-SD) negative international oil price shock. Following a decline in oil prices, the oil firms become less profitable, leading to a decline in their output and a reduction in the oil firms' demand for materials sourced from the domestic economy (as implied by equation 17). In view of the size of the oil sector as well as the impacts of oil price declines on government consumption, aggregate GDP falls and the effect is quite persistent. However, private consumption rises as more income becomes available to households following a negative oil price shock- oil constitutes part of the consumption basket of the household in our model, implying that a decline in oil price releases more resources to households to spend. A negative oil price shock causes the non-oil sector to become relatively more attractive as more productive resources are directed from the oil to the non-oil sector. The inflow of productive resources into the non-oil sector as well as the increased private consumption and reduced marginal cost lead to an increased in non-oil GDP. However, the increase in non-oil output is suppressed initially due to the reduced demand for non-oil goods by the oil sector. 

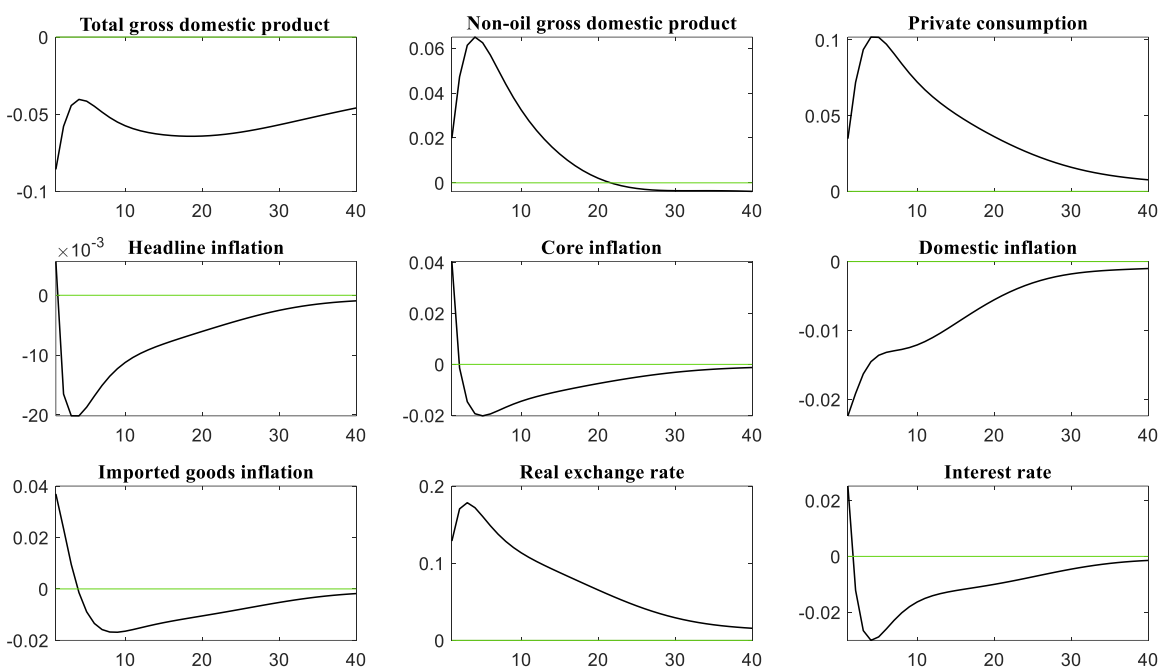

Figure 5: Impulse responses to a one-SD negative oil price shock

Since the price of fuel features in the real marginal cost equation of domestic firms (equation 13), a negative oil price shock generates lower marginal cost and leads to a fall in domestic inflation. However, the instrumentality of exchange rate pass-through causes import prices to rise following a depreciated exchange rate. The combined effects of a negative oil price shock on the prices of domestic and imported goods causes core inflation to increase. Thus, the increases in headline and core measures of inflation are induced by the depreciation in exchange rate. The monetary authority responds to the initial exchange rate-induced rise in headline inflation by embarking on an interest rate hike, a move that further exacerbates the contractionary effects of the negative oil price shock on the aggregate GDP. In a nutshell, a negative international oil price shock generates aggregate GDP contraction, increase in non-oil GDP, reduction in domestic inflation, exchange rate depreciation, increases in headline and core measures of inflation, and an interest rate hike in our small open resource-rich economy.

\subsubsection{Macroeconomic implications of fuel subsidy removal}

In this sub-section, we simulate two economies based on different assumptions regarding the size of the pass-through effect of oil prices into the retail price of fuel. The first economy is based on a benchmark model under which the fuel pricing parameter is set at $v=0.43$. The second economy is based on an alternative model simulated under an assumption of complete pass-through effect, such that $v=1$ (i.e. a no subsidy regime). The responses of the economy a decline in oil price (equivalent 
to a one-SD negative real oil price shock) under these two alternative economies are presented in Figure 6.
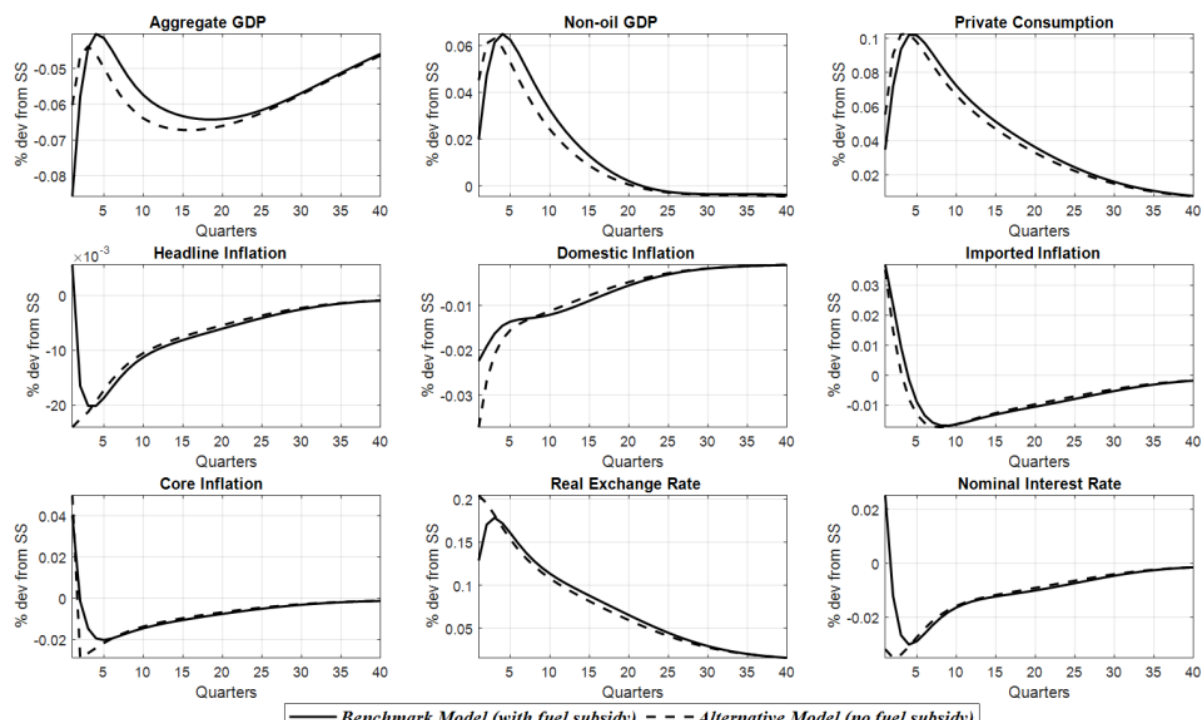

Figure 6: Impulse responses under different assumptions regarding fuel subsidies

Following a one-SD negative real oil price shock, aggregate GDP in the domestic economy contracts. However, the contraction under a model with fuel subsidies $(v=0.43)$ is more severe in the short run. In other words, fuel subsidy removal ameliorates the contractionary effects of a negative oil price shock in our small open economy. Non-oil GDP increases in the aftermath of a negative oil price shock due to the associated lower real marginal cost faced by the firms as well as the increased aggregate demand arising from additional income that is available to consumers. Thus, private consumption rises. Similar to the case under aggregate GDP, better outcomes are recorded for non-oil GDP and private consumption under a model without fuel subsidies $(v=1)$ in line with the findings of Siddig et al. (2014). That is, the increases in nonoil output and private consumption associated with a negative oil price shock are higher under an economy without fuel subsidies, compared to the case for an economy with a fuel subsidy regime.

Given a negative oil price shock, Figure 6 shows that domestic inflation declines more under a model without fuel subsidies $(v=1)$, owing to the complete pass-through effect of international oil prices into the retail price of fuel. Thus, the effects of the negative oil price shock are fully reflected in firms' real marginal cost, leading to a downward adjustment in the 
prices of domestically produced goods. In other words, the fuel subsidy regime adds additional stickiness to the evolution of domestic prices, which causes domestic inflation to be rigid downwards. The behaviours of imported and core measures of inflation are quite similar in both qualitative and quantitative terms. However, the immediate impact of a negative oil price shock on headline inflation differs under the two models. Upon impact, headline inflation declines under the benchmark model following a negative shock to oil price while the decline is delayed under the alternative model. The delayed response of headline inflation under the alternative model can be explained by the price rigidity implied by the fuel subsidy programme. Though the real exchange rate depreciates more under the model without fuel subsidies, the inflationary impacts of such depreciation on headline inflation is more than offset by the reduction in domestic inflation under such a regime (i.e. $v=1$ ). On the other hand, the inflationary effects of exchange rate depreciation cause headline inflation to rise under the economy with fuel subsidies $(v=0.43)$ since domestic inflation is sticky downwards.

Consequently, the monetary authority of an economy with a fuel subsidy regime increases interest rate following a negative oil price shock, a move that pushes the economy further into recession (Figure 6). On the other hand, the monetary authority of an economy without a fuel subsidy regime faces no inflation threats following a negative oil price. It, therefore, cuts rates in the bid to boost aggregate demand and increase domestic output. Of course, such a move causes an immediate exchange rate overshooting as against the case under the benchmark model where a delayed overshooting is observed (Figure 6). These results are useful in helping to understand the issues relating to the macroeconomic implications of potential fuel subsidy reforms in Nigeria.

In order to investigate the level of macroeconomic instabilities associated with fuel subsidy removal, we report the variances of selected macroeconomic variables under the benchmark and alternative models in Table 5. It can be seen from the table that, given an oil price shock, the alternative model is associated with slightly higher volatility in aggregate GDP, headline inflation, core inflation, domestic inflation, real exchange rate, and the nominal interest rate. On the other hand, non-oil GDP, private consumption, and imported inflation are insignificantly less volatile under a no subsidy regime. 
Table 5: Variances of selected macroeconomic variables under different assumptions regarding fuel subsidies

\begin{tabular}{lcc}
\hline Variable & Benchmark (subsidy) & Alternative (no Subsidy) \\
\hline Aggregate GDP & 0.1769 & 0.1841 \\
Non-oil GDP & 0.0281 & 0.0245 \\
Private consumption & 0.1060 & 0.1016 \\
Headline inflation & 0.0033 & 0.0038 \\
Core inflation & 0.0055 & 0.0076 \\
Domestic inflation & 0.0032 & 0.0046 \\
Imported inflation & 0.0058 & 0.0053 \\
Real exchange rate & 0.3208 & 0.3307 \\
Interest rate & 0.0076 & 0.0089 \\
\hline
\end{tabular}

Overall, the results of our counterfactual simulations indicate that the extant fuel subsidy regime in the country has non-trivial implications for the economy's response to an oil price shock. In view of the macroeconomic instabilities observed under the alternative model, this paper cautions that potential future subsidy reforms must be conducted with due diligence. While the fiscal sustainability implications of the fuel subsidy programme remain a source of concern to policy makers, this paper calls for a more expansive study to assess such implications and evaluate the welfare impacts of potential subsidy reforms.

\subsection{Conclusion and Policy Implications}

The debates around the macroeconomic implications of oil price shocks as well as the relevance of the extant fuel subsidy regime in Nigeria has remained intense over the years. At the global level, international organisations and policy makers have raised concerns regarding how welltargeted energy subsidies have been, especially with regards to protecting the poor segment of the society. Those who believe that energy subsidies have outlived their usefulness have called for its abolition in order to free up fiscal resources for economic development. In Nigeria, while the fuel subsidy debate continues to gather steam, studies addressing the welfare and macroeconomic implications of its removal are still relatively scanty.

Results from our estimated DSGE model show that the pass-through effect of international oil prices into domestic fuel price is about 43 per cent. We indicate that the size of the pass-through parameter governs the dynamics of fuel subsidy payments in the country and simulated two models based on different assumptions regarding the parameter: (i) $\nu=0.43$, corresponding to an economy with a subsidy regime, and (ii) $v=1.0$, 
corresponding to an economy without a fuel subsidy regime. Our results show that oil price shocks have non-trivial implications for output, prices and interest rate in our small open economy. While a negative oil price shock leads to a contraction in aggregate GDP, the severity of the contraction is amplified under the model with fuel subsidies. The paper, however, notes that retaining the subsidy programme has some appeal in terms of its ability to generate relative macroeconomic stability, compared to the case under a no-subsidy regime.

Although the subsidy regime is useful for stabilising the domestic economy, its effects on long run growth, agent's welfare and government's fiscal operations require further investigation. The findings of such investigation would provide useful insights relating to the fiscal sustainability of the subsidy programme as well as how best the government could proceed with future reforms. In view of the findings of this study, we caution that a successful exit strategy must necessarily accommodate the deployment of well-targeted safety nets as well as the evolution of sustainable adjustment mechanisms.

\section{References}

Abayomi, A., Adam, S. O., \& Alumbugu, A. (2015). Oil exportation and economic growth in Nigeria. Developing Country Studies, 5(15), 83-92.

Abdulkareem, A., \& Abdulhakeem, K. A. (2016). Analysing oil pricemacroeconomic volatility in Nigeria. CBN Journal of Applied Statistics, 7(1), 1-22.

Adebiyi, M. A., \& Mordi, C. N. O. (2016). A dynamic stochastic general equilibrium (DSGE) model of exchange rate pass-through to domestic price in Nigeria. Central Bank of Nigeria Occasional Paper, (59).

Adenikinju, A. (2009). Energy pricing and subsidy reforms in Nigeria, in 'OECD Conference Centre, Paris 910 June 2009'.

Adeniyi, O., Oyinlola, A. \& Omisakin, O. (2011). Oil price shocks and economic growth in Nigeria: are thresholds important? OPEC Energy Review, 35(4), 308-333.

Aigheyisi, O. S. (2018). Oil price volatility and business cycles in Nigeria. Studies in Business and Economics, 13(2), 31-40. 
Akinleye, S. O., \& Ekpo, S. (2013). Oil price shocks and macroeconomic performance in Nigeria. Economía Mexicana. Nueva Época.

Akinlo, A. E. (2012). How important is oil in Nigeria's economic growth? Journal of Sustainable Development, 5(4), 165.

Alege, P. O. (2012). A business cycle model for Nigeria. CBN Journal of Applied Statistics, 3(1), 85-115.

Algozhina, A. (2015). Optimal monetary policy rule and cyclicality of fiscal policy in a developing oil economy. A paper presented at the 15th Annual Dynare Conference held in Brussels, September 28-29, 2015

Allegret, J. P., \& Benkhodja, M. T. (2015). External shocks and monetary policy in an oil exporting economy (Algeria). Journal of Policy Modelling, 37(4), 652-667.

Alleyne, T. S. C., \& Hussain, M. (2013). Energy subsidy reform in SubSaharan Africa: Experiences and lessons. International Monetary Fund.

Anand, R., Coady, D., Mohommad, M. A., Thakoor, M. V. V., \& Walsh, M. J. P. (2013). The fiscal and welfare impacts of reforming fuel subsidies in India. International Monetary Fund.

Bazilian, M., \& Onyeji, I. (2012). Fossil fuel subsidy removal and inadequate public power supply: Implications for businesses. Energy Policy, 45, 1-5.

Berument, M. H., Ceylan, N. B., \& Dogan, N. (2010). The impact of oil price shocks on the economic growth of selected MENA countries. The Energy Journal, 149-176.

Breton, M., \& Mirzapour, H. (2016). Welfare implication of reforming energy consumption subsidies. Energy policy, 98, 232-240.

Budgit (2019). Nigeria's petrol subsidy regime: dilemma of the world's most populous black nation. Budgit Policy Brief.

Calvo, G. A. (1983). Staggered prices in a utility-maximizing framework. Journal of Monetary Economics, 12(3), 383-398. 
Calvo-Gonzalez, O., Cunha, B., \& Trezzi, R. (2015). When winners feel like losers: evidence from an energy subsidy reform. The World Bank Economic Review, 31(2), 329-350.

Clements, B. J., Coady, D., Fabrizio, S., Gupta, S., Alleyne, T. S. C., \& Sdralevich, C. A. (2013). Energy subsidy reform: lessons and implications. International Monetary Fund.

Coady, D. P., Flamini, V., \& Sears, L. (2015). The unequal benefits of fuel subsidies revisited: Evidence for developing countries. International Monetary Fund.

Coady, D., Parry, I., Sears, L., \& Shang, B. (2017). How large are global fossil fuel subsidies? World development, 91, 11-27.

Dennis, A. (2016). Household welfare implications of fossil fuel subsidy reforms in developing countries. Energy Policy, 96, 597-606.

Di Bella, G., Norton, L., Ntamatungiro, J., Ogawa, S., Samake, I., \& Santoro, M. (2015). Energy subsidies in Latin America and the Caribbean: stocktaking and policy challenges. International Monetary Fund.

Ebeke, M. C., \& Ngouana, M. C. L. (2015). Energy subsidies and public social spending: Theory and evidence. International Monetary Fund.

EFInA. (2018). Access to Financial Service in Nigeria Survey. Retrieved from https://www.efina.org.ng/our-work/research/access/

Estache, A., \& Leipziger, D. (Eds.) (2009). Stuck in the middle: Is fiscal policy failing the middle class? Brookings Institution Press.

Ferrero, A., \& Seneca, M. (2019). Notes on the underground: Monetary policy in resource-rich economies. Journal of Money, Credit and Banking, 51(4), 953-976.

Fueki, T., Higashi, H., Higashio, N., Nakajima, J., Ohyama, S., \& Tamanyu, Y. (2018). Identifying oil price shocks and their consequences: the role of expectations in the crude oil market. BIS Working Paper.

Gabriel, V., Levine, P., Pearlman, J., \& Yang, B. (2010). An estimated DSGE model of the Indian economy. NIPE WP 29, 2010. 
Gali, J., \& Monacelli, T. (2005). Monetary policy and exchange rate volatility in a small open economy. The Review of Economic Studies, 72(3), 707-734.

Gupta, R., Hollander, H., \& Wohar, M. E. (2016). The impact of oil shocks in a small open economy New-Keynesian dynamic stochastic general equilibrium model for South Africa. University of Pretoria, Department of Economics.

Hamilton, J. D. (1983). Oil and the macroeconomy since world war II. Journal of political economy, 91(2), 228-248.

Hollander, H., Gupta, R., \& Wohar, M. E. (2018). The impact of oil shocks in a small open economy New-Keynesian dynamic stochastic general equilibrium model for an oil-importing country: The case of South Africa. Emerging Markets Finance and Trade, 55(7), 1593-1618.

Iklaga, F. O. (2017). Estimated and optimised monetary policy rules for resource-rich emerging economies. PhD thesis, University of Surrey.

Jakob, M., Chen, C., Fuss, S., Marxen, A., \& Edenhofer, O. (2015). Development incentives for fossil fuel subsidy reform. Nature Climate Change, 5(8), 709.

Krane, J., \& Monaldi, F. (2017). Oil prices, political instability, and energy subsidy reform in MENA oil exporters. Center for Energy Studies, Baker III Institute for Public Policy, Rice University.

Medina, J. P., \& Soto, C. (2005). Oil shocks and monetary policy in an estimated DSGE model for a small open economy. Central Bank of Chile Working Paper 353.

Medina, J. P., \& Soto, C. (2007). The Chilean business cycles through the lens of a stochastic general equilibrium model. Central Bank of Chile Working Paper 457.

Monacelli, T. (2005). Monetary policy in a low pass-through environment. Journal of Money, Credit and Banking, 37(6), 1047-1066. 
Ncube, M., \& Balma, L. (2017). Oil shocks, public investment and macroeconomic and fiscal sustainability in Nigeria: Simulations using a DSGE model. QGRL Working Paper, (2017/01).

Ocheni, S. I. (2015). Impact of fuel price increase on the Nigerian economy. Mediterranean Journal of Social Sciences, 6(1S1), 560.

Olayeni, O. R., \& Olabode, P. O. (2013). A small open economy model for Nigeria: A DSGE framework. Journal of Economic and Financial Modelling, 1(1), 1-13.

Omotosho, B. S. (2019). Business Cycle Fluctuations in Nigeria: Some Insights from an Estimated DSGE Model. MPRA Paper 98351, University Library of Munich, Germany. Retrieved from https://ideas.repec.org/p/pra/mprapa/98351.html

Poghosyan, T., \& Beidas-Strom, S. (2011). An estimated dynamic stochastic general equilibrium model of the Jordanian economy. IMF Working Paper, 11(28).

Rasaki, M. G., \& Malikane, C. (2015). Macroeconomic shocks and fluctuations in African economies. Economic Systems, 39(4), 675-696.

Romero, R. E. (2008). Monetary policy in oil-producing economies. CEPS Working Paper (169).

Salehi-Isfahani, D., Wilson Stucki, B., \& Deutschmann, J. (2015). The reform of energy subsidies in Iran: The role of cash transfers. Emerging markets finance and trade, 51(6), 1144-1162.

Schorfheide, F. (2000). Loss function-based evaluation of DSGE models. Journal of Applied Econometrics, 15(6), 645-670.

Sdralevich, C. A., Sab, R., Zouhar, Y., \& Albertin, G. (2014). Subsidy reform in the Middle East and North Africa: Recent progress and challenges ahead. International Monetary Fund.

Senbeta, S. (2011). A small open economy New-Keynesian DSGE model for a foreign exchange constrained economy.University of Antwerp, Faculty of Applied Economics. 
Siddig, K., Aguiar, A., Grethe, H., Minor, P., \& Walmsley, T. (2014). Impacts of removing fuel import subsidies in Nigeria on poverty. Energy Policy, 69, 165-178

Smets, F., \& Wouters, R. (2007). Shocks and frictions in us business cycles: A Bayesian DSGE approach. American economic review, 97(3), 586-606.

Umar, H. M., \& Umar, M. S. (2013). An assessment of the direct welfare impact of fuel subsidy reform in Nigeria. American Journal of Economics, 3(1), 23-26. 